\section{On the Crystal Structure of Hydrated Sodium Peroxoborate}

\author{
A R N F H A S S O N
}

Institute of Chemistry, University of Uppsala, Uppsala, Sweden

There is some controversy about the nature of the compound that crystallizes from $\mathrm{s}$ water solution of sodium borate and hydrogen peroxide. Thus it has been described both as $\mathrm{NaBO}_{2} \cdot \mathrm{H}_{2} \mathrm{O}_{2} \cdot 3 \mathrm{H}_{2} \mathrm{O}$ and as $\mathrm{NaBO} \cdot 4 \mathrm{H}_{2} \mathrm{O}$.

The author obtained crystals of the compound from a solution of $3.5 \mathrm{~g}$ borax, $0.35 \mathrm{~g}$ $\mathrm{NaOH}$ and $9 \mathrm{ml} 30 \% \mathrm{H}_{2} \mathrm{O}_{2}$ in $125 \mathrm{ml}$ water. Analyses of the sodium, boron and active oxygen contents of the crystals were in agreement with the composition given by the above formulae. Weissenberg photographs were taken of two single crystals rotated around different axes. Comparison of single crystal photographs and powder photographs established that only one substance had crystallized from the solution. The intensities of 500 independent reflexions were estimated. The triclinic unit cell contains one formula unit $\mathrm{Na}_{2} \mathrm{~B}_{2}\left(\mathrm{O}_{2}\right)_{2}(\mathrm{OH})_{4} .6 \mathrm{H}_{2} \mathrm{O}$ and has the dimensions $a=7.34 \AA, b=6.81 \AA, c=8.15 \AA$, with $a=101^{\circ}, \beta=110^{\circ}$ and $\gamma=120^{\circ}$. The space group is $\mathrm{P} \overline{\mathrm{l}}$.

The structure has been determined by means of Harker-Kasper inequalities and three dimensional Patterson functions and has been verified by comparison of one calculated and one observed three dimensional electron density function. The unrefined parameters are given in Table 1.

There is one centrosymmetrical anion in the unit cell. The arrangement of the atoms is shown in Fig. 1. The bond distan-

Table 1. The unrefined parameters of $\mathrm{Na}, \mathrm{O}$ and $B$ atoms.

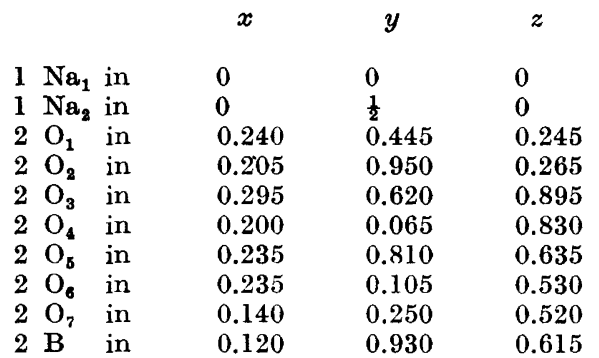

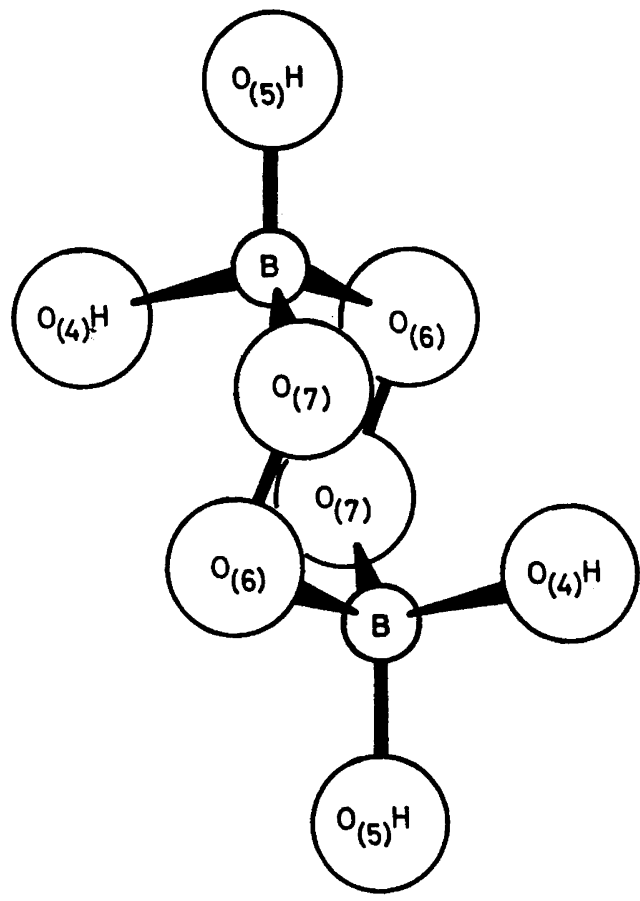

Fig. 1. The shape of the $\mathrm{B}_{2}\left(\mathrm{O}_{2}\right)_{2}(\mathrm{OH})_{4}{ }^{2-}$ ion.

ces and the bond angles in the negative ion are given in Tables 2 and 3. The B-O distances are in agreement with those reported earlier for tetrahedrally coordinated boron atoms ${ }^{1}$. The bond angles at the oxygen atoms and the bond distance within the peroxo group agree with the values reported for $\mathrm{H}_{2} \mathrm{O}_{2}{ }^{2}$. The dihedral angle is $64^{\circ}$ (Fig. 2).

The sodium ions are at symmetry centres of oxygen octahedra which share opposite edges. A part of the octahedral chains is shown in Fig. 3. Relevant bond distances are given in Table 4. The chains are parallel to the $b$-axis. The shared oxygen atoms

Table 2. Bond distances within the peroxoborate ion,

$\begin{array}{ll}\mathrm{B}-\mathrm{O}_{4} & 1.54 \AA \\ \mathrm{B}-\mathrm{O}_{5} & 1.44 \AA \\ \mathrm{B}-\mathrm{O}_{6} & 1.52 \AA \\ \mathrm{B}-\mathrm{O}_{7} & 1.42 \AA \\ \mathrm{O}_{6}-\mathrm{O}_{7} & 1.47 \AA\end{array}$

Acta Chem. Scand. 15 (1961) No. 4 
Table 3. Bond angles within the peroxoborate ion.

$\begin{array}{ll}\mathrm{O}_{4}-\mathrm{B}-\mathrm{O}_{5} & 101^{\circ} \\ \mathrm{O}_{4}-\mathrm{B}-\mathrm{O}_{6} & 116^{\circ} \\ \mathrm{O}_{4}-\mathrm{B}-\mathrm{O}_{7} & 115^{\circ} \\ \mathrm{O}_{5}-\mathrm{B}-\mathrm{O}_{6} & 104^{\circ} \\ \mathrm{O}_{5}-\mathrm{B}-\mathrm{O}_{7} & 112^{\circ} \\ \mathrm{O}_{6}-\mathrm{B}-\mathrm{O}_{7} & 108^{\circ} \\ \mathrm{B}-\mathrm{O}_{6}-\mathrm{O}_{7} & 107^{\circ} \\ \mathrm{B}-\mathrm{O}_{7}-\mathrm{O}_{6} & 107^{\circ}\end{array}$

belong to water molecules. The sodium ions link the negative ions in the following way. In alternate octahedra in each chain, the two unshared oxygen atoms are incorporated in $\mathrm{O}\left({ }_{4}\right) \mathrm{H}$-groups from two negative ions. In every other octahedron each unshared oxygen atom forms part of a water molecule which is linked in turn by a hydrogen bond to an $\mathrm{O}\left({ }_{5}\right) \mathrm{H}$-group in a different negative ion.

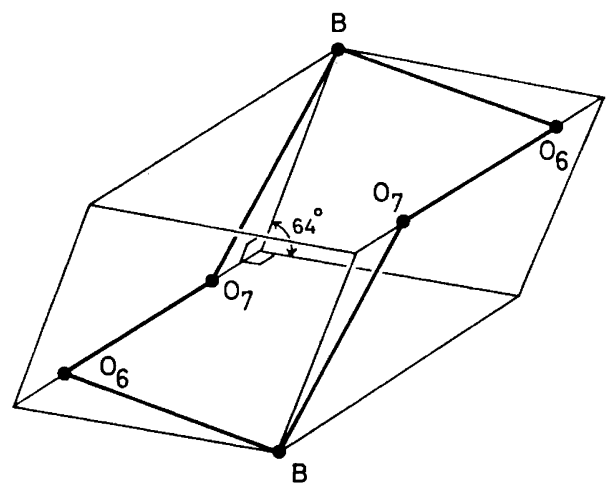

Fig. 2. The double peroxo bridge connecting two boron atoms.

The complete structure determination will be published when the refinement of the parameters has been completed.

Table 4. Bond distances between sodium and oxygen atoms.

$\begin{array}{ll}\mathrm{Na}_{1}-\mathrm{O}_{1} & 2.46 \AA \\ \mathrm{Na}_{1}-\mathrm{O}_{2} & 2.37 \AA \\ \mathrm{Na}_{1}-\mathrm{O}_{4} & 2.29 \AA \\ & \\ \mathrm{Na}_{2}-\mathrm{O}_{1} & 2.40 \AA \\ \mathrm{Na}_{2}-\mathrm{O}_{2} & 2.61 \AA \\ \mathrm{Na}_{2}-\mathrm{O}_{3} & 2.42 \AA\end{array}$

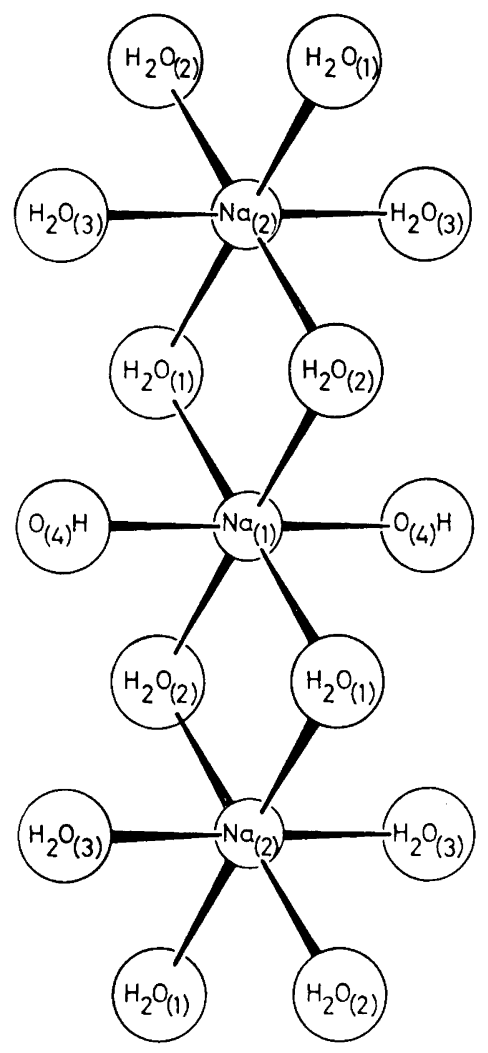

Fig. 3. Part of the chains of octahedra.

The author wishes to express his thanks to Prof. G. Hägg for all the facilities placed at his disposal, to Dr. I. Lindqvist for suggesting the problem and to Mr. Allan Brown for linguistic corrections of the manuscript. This investigation has been sponsored by grants from the Nobel Foundation and from Anslaget till främ. jande av ograduerade forskares vetenskapliga verksamhet. Facilities for the use of the digital computer BESK were granted by the Swedish Board for Computing Machinery.

1. Pauling, L. The Nature of the Chemical Bond. Cornell University Press, Ithaca, N. Y. 1960.

2. Tables of Interatomic Distances and Configu. ration in Molecules and Ions, The Chemical Society, London 1958.

Received May 12, 1961. 